\title{
Institutionalization of planetary management boundaries
}

\author{
Olesya Ryazanova $^{1}$, Taisiya Kashtelian $^{2}$, Vera Zolotareva ${ }^{3 *}$ and Anna Ryabokon ${ }^{2}$ \\ ${ }^{1}$ Moscow State Institute of International Relations (University), 119454, Moscow, Russia \\ ${ }^{2}$ Belarussian State Technological University, 220006, Minsk, Republic of Belarus \\ ${ }^{3}$ Moscow Polytechnic University, 115280, Moscow, Russia
}

\begin{abstract}
Within the framework of the problem of institutionalization of planetary management boundaries, planetary property and planetary rent are considered as the idea of radical institutional -economic innovation designed to form the economy of optimal resource use and equitable distribution of world income. The authors use a systemic approach that emphasizes the importance of institutional analysis of rent-oriented behavior. The relevance and timeliness of theoretical and methodological approaches of the planetary management boundaries paradigm for all sectors of the economy, including agro-industrial complex. The relationship of agro-industrial and forest complexes in the mechanism of use of planetary land resources is traced. Particular attention is paid to forest rents as a value positioned in the aspect of the global bioeconomic system and plays an important role in the process of its evolution. The authors note the inevitability of conflicts of rent relations on the planetary scale, the solution of which requires the unification of efforts of the entire global scientific community.
\end{abstract}

\section{Introduction}

Sharp change in the planetary balance of resources in technogenic conditions of the XXI century significantly limited their volume, which strengthened the law of natural resources limitness (exhaustibility) and updated the problem of using such resource as land. Analysis of planetary land structure shows that the proportion of land under cultivation is only $11 \%$. In addition, the proportion of land with low productivity is extremely high $-31 \%$. All this has a direct impact on the solution of one of the most important global problems of our time — the food problem - and prioritizes the need for innovative development of agro-industrial complex.

However, the process of its innovative development and creation of agro-industrial complex of the future is impossible without analysis and further theoretical and methodological development within the framework of the paradigm of planetary management boundaries, the institution of planetary property as the legal basis of management, and planetary rent as an economic result of reproduction processes of natural resources.

\footnotetext{
${ }^{*}$ Corresponding author: zolotareva2005@mail.ru
} 
Currently, the rights to the most of the planet's natural resources are enshrined within national ownership systems and are regulated by each country's institutions, legislation and economic traditions. Meanwhile, today there are many problems that require the harmonization of national and world interests, actions and programs [1]. The creation of a global macroeconomic planetary management model would remove many contradictions of political, economic, technological and legal nature, distinctly manifested in modern conditions.

Despite the available publications on the subject, many aspects of it have not been sufficiently researched, both because of its scale, multidimensionality and multidisciplinary nature, and because of the deep interests contradictions of the main economic entities of the world economy.

From all the above, we can draw conclusions that the search for answers to the following questions is relevant and timely: what is the system of planetary boundaries positioning in economic reality, what is the role of planetary property in the realization of economic interests of society, as well as what are the directions of planetary rent realization as a special income belonging to all mankind in the light of modern challenges of planetary development.

The purpose of this study is to consider within the paradigm of planetary management boundaries of such important economic institutions as planetary property and planetary rent and, in particular, its variety - forest rents. As well as identifying the role of these institutions in improving the efficiency of the planetary land resources use, including in the agro-industrial complex.

\section{Materials and Methods}

Methodological basis of analytical interpretation of the problem of planetary management boundaries was the works of domestic and foreign scientists considering the role of institutions in economic development, questions of planetary ownership, evolution of rent theory and, in particular, planetary rent and its individual constituents [2-7, 10-16].

The contradiction of the transformation process of existing institutions and formation of new ones was reflected in the teaching of T. Veblen, according to which institutions have both positive, stimulating and negative and inhibiting influence on the development of the economic system, much more for the evolving system. Therefore, in his opinion, "changes not the market mechanism itself, but institutions, institutional environment, customs, laws; each country has its own specific institutions, so it is necessary to study not ideal schemes, but real... structures" [Social rent as a phenomenon of the modern world].

At the same time, the institution of ownership is a priority in global transformation. The research situation, which is the dilemma of private and public forms of ownership, on the world scale was "turned" by E. Ostrom. The approaches identified by her allowed to speak not so much about the forms of ownership in its organizational and legal understanding, but rather about the special "collectivism" (community), or rather institutional rules and regulations allowing to influence the return of natural assets in the best way, the principles of social capital accumulation and planetary rents in general. The merit of E. Ostrom is in protection of institutional diversity that contributes to solving problems of environmental management economy efficiency through public choice in favor of sustainable management [3].

The theory of rent has an important role in methodological terms, as rent as a ratio of redistribution and scattering of value is the key complex and multifunctional phenomenon value, which has a major impact on the sphere of economic entities activation $[8,9]$. It should be noted that the definitions of the neoclassical approach are now successfully supplemented by institutional models of the development of the socio-economic phenomenon of rent as a cost, embodying the mechanism that implements the economic interrelations between the 
market and the state and the smoothing contradictions of the economy - society system in the aspect of achieving harmony with the environment and its "borderline" potential.

\section{Results and Discussion}

The effectiveness of the allocation and use of any kind of resource is primarily determined by the form of ownership, so the institution of ownership plays an important role.

Within planetary boundaries, planetary ownership is the highest form of public ownership development of shared consumption facilities, which can become a real financial, economic and legal basis for integration in the implementation of the human strategy for sustainable economic development [5]. Its recognition as a special institution was reflected in the decisions of the 1992 UN Conference on the Environment in Rio de Janeiro and in a number of subsequent documents.

The mechanism of planetary property realization is most significantly and "ambiguously" manifested in the field of planetary resources exploitation, possessing the following features:

- are fundamental and systemic for all other types of resources, that is, without which the sustainability and reproduction of the Earth as a holistic system is impossible;

- are inalienable and unassignable, because of their magnitude and systemic nature, they exceed the norms, claims and limitations of any national system of law.

Ownership and realization of ownership rights over planetary resources belong to all mankind. However, humanity, as a collective planetary entity, is in practice represented in part, situational, in some aspect of enforcement. Therefore, all 11 rights (according to the Honoré classification) to planetary property are shared by structures, institutions, organizations acting both on behalf of all mankind and on behalf of separate groups [6].

Globalization processes objectively contribute to the unification of economic institutions for their functioning on a global scale, stimulating the development of specialization of regional sectors of the world economy and, in particular, the agro-industrial complex. To the problem of environmental management, these processes have introduced requirements to align national interests with the common human ones in terms of the use of planetary resources and the private appropriation of the corresponding rents dubbed planetary.

Planetary rent can be considered as the next historical phase of rent institution development, the highest stage of its evolution, in which the contradiction associated with excess income alienation is removed [7].

In fact, planetary rent contains the same characteristics as traditional rent, representing the income from the factor of production, the source of which is its limited nature, and the legal basis is the natural monopoly of the resource owner. Comparative analysis of classical and planetary rents is shown in Table 1 .

Table 1. Differences of classical and planetary rent [7, p. 356]

\begin{tabular}{|l|l|l|}
\hline \multicolumn{1}{|c|}{ Criteria } & \multicolumn{1}{|c|}{ Classic rent } & \multicolumn{1}{c|}{ Planetary rent } \\
\hline Purpose & Owner's enrichment & $\begin{array}{l}\text { Creating a planetary budget to provide the } \\
\text { financial base of the planetary economy } \\
\text { and solve the global problems of the } \\
\text { modern world }\end{array}$ \\
\hline Ownership & Private, state & Planetary (universal) \\
\hline $\begin{array}{l}\text { Conditions of } \\
\text { occurrence }\end{array}$ & $\begin{array}{l}\text { Inequality of conditions and } \\
\text { opportunities for production } \\
\text { activities }\end{array}$ & $\begin{array}{l}\text { Equality before the need to follow the } \\
\text { universal discipline of production } \\
\text { activities }\end{array}$ \\
\hline Income extraction & $\begin{array}{l}\text { Uses both legal and open } \\
\text { and illegal, hidden tools }\end{array}$ & Uses only legal and open tools \\
\hline
\end{tabular}




\begin{tabular}{|l|l|l|}
\hline Income distribution & $\begin{array}{l}\text { Proportional and } \\
\text { disproportional }\end{array}$ & $\begin{array}{l}\text { Proportional (in the interest of all } \\
\text { mankind) }\end{array}$ \\
\hline Function & $\begin{array}{l}\text { Mechanism of enrichment } \\
\text { of a narrow group of } \\
\text { persons }\end{array}$ & $\begin{array}{l}\text { Mechanism of the world economy } \\
\text { transformation in order to solve global } \\
\text { problems, transition to rational } \\
\text { environmental management and resource } \\
\text { substitution, as well as ensuring the } \\
\text { principles of social justice }\end{array}$ \\
\hline
\end{tabular}

History shows that the mechanism and institution of rent is transformed, developed and implemented in such forms of natural rent as land, forest, oil, water, mountain, atmospheric and other forms.

An important type of planetary rent is forest rent, due to the significant share of forest resources in the structure of planetary land resources (31\%) and their involvement in the sphere of public requests [8].

Institutional analysis of organization ways of rent relations unites the transactions spheres concerning transfer of ownership of natural forest resources from "passing from hand to hand", positioning proprietor as owners and those economic agents who have rights to assign rents, a broad "range" of principal-agent interactions in the context of value formation to the natural environment improvements.

In theoretical terms, a big influence on the institutionalization of the problem of rent relations has the model of positioning ways of organization and institutional registration of socio-ecological-economic interests of modern society. It is based on numerous claims of consumers, social, ethical, moral aspects of economic development and transformation in the face of environmental challenges of modern times.

The matrix model of sustainable development of the forest sector based on the main source of forest ecosystems raw materials (wood resources) reflects the system of interlinks of economic reality complemented by development of tertiary sector - ecosystem service [6]. It includes social factors of the global order, as well as institutional and locationdependent causes of natural resources. A major role belongs to the functional approach of the supply chain, as well as the many, often unidentifiable by the traditional cost institution categories, conditions for the formation of life product cycles that have both local and institutional and generally global environments. One important global effect is food security and crop opportunities (see Table 2).

Table 2. Ecological and economic aspect of statistical study of circular forest bioeconomics [10]

\begin{tabular}{|l|c|c|c|c|c|}
\hline $\begin{array}{c}\text { Approaches/ } \\
\text { effects }\end{array}$ & \multicolumn{2}{|c|}{ Global } & \multicolumn{2}{c|}{ Landscape } & Supply chains \\
\hline $\begin{array}{l}\text { Mitigating } \\
\text { climate } \\
\text { change }\end{array}$ & $\begin{array}{c}\text { Total carbon } \\
\text { sequester } \\
\text { effect }\end{array}$ & $\begin{array}{c}\text { Assimilation } \\
\text { of harmful } \\
\text { substances }\end{array}$ & - & - & - \\
\hline Biodiversity & Food safety & - & $\begin{array}{c}\text { Conservation } \\
\text { of biodiversity }\end{array}$ & $\begin{array}{c}\text { Control of } \\
\text { invasive } \\
\text { species }\end{array}$ & $\begin{array}{c}\text { Standards of } \\
\text { consumption } \\
\text { (destruction) }\end{array}$ \\
\hline $\begin{array}{l}\text { Material (raw } \\
\text { material, } \\
\text { water, in } \\
\text { particular), } \\
\text { socio- } \\
\text { economic } \\
\text { flow }\end{array}$ & - & $\begin{array}{c}\text { Clean water, } \\
\text { opportunities } \\
\text { for cultivation } \\
\text { of crops }\end{array}$ & Employment & - & $\begin{array}{c}\text { Distribution in } \\
\text { value chains } \\
\text { based on } \\
\text { product } \\
\text { lifecycle (PLC) }\end{array}$ \\
\hline $\begin{array}{l}\text { Recreational } \\
\text { flow }\end{array}$ & - & - & Hunting & Tourism & - \\
\hline
\end{tabular}


Having a variety of approaches presented in Table 2 to assess the prospects for a statistical study of the development of forest systems and the forest industry, as well as related production systems that involve both organic raw material and food production and recreation, sustainable agroforestry systems, improvement of environmental impact in the environmental repercussion system in sectors of water supply and infrastructure (medical tourism, for example), and the creation of new ecosystem destinations (for example, marshes) related to the carbon sequester and, in general, the development of a global welfare, it is possible to draw conclusions about a broad "dialogue" field for the creation of a modern model for the formation of production, distribution and consumption of forest rents, corresponding to the social and ecological -economic paradigm of planetary management boundaries.

In the conditions of the modern times challenges, the balance of strategic goals of forest industries' innovative development should be taken into account with constant search for solutions to ensure innovative development of agro-industrial complex, the relationship between which is indisputable. Institutional transformation in this direction should yield tangible results for economic entities and the population.

Forests of Russia and Belarus are a natural biofilter of a huge part of the Euro-Asian continent, contribute to social, ecological well-being and food independence of countries. In Belarus, for example, a number of institutional activities are being planned to realize opportunities for the transition from minerals to widespread use of forest renewable resources. Since 2016, the Republic of Belarus has an updated Forest Code. A number of regulatory documents have been adopted to identify ecosystem services, and institutional strengthening of the aesthetic and cultural values of landscapes are being carried out.

In the economic activities of the forestry sector of Belarus, attempts are being made to create bioenergy chains of value creation. The scientific knowledge system evaluates alternatives on how to handle the slashes, taking into account nutrient content in the soil and land cover and other factors. The enumerated solutions to the institutionalization of the forest rents problem only sporadically characterize those key development points that are recorded by statistics and provide data on forest condition as a result of the inevitably high consumption of this planetary resource.

Globaltrends and priorities of economic development of modern times have changed towards formation of planetary rent as a category of global order. Today, emerging conflicts of rent relations objectively require the institutionalization of planetary management boundaries, an important role in which is taken by supranational regulatory authorities. Planetary rents must be formed and used in such a way that the intellectual resources that are "fuelled" by it (through the distribution and consumption system) enable institutional containment of high environmental risks and environmental degradation. It should also stimulate innovative development of agro-industrial complex and related spheres as the most important source of this development.

\section{Conclusion}

Transformation processes in the world economic system in the XXI century actualized the problem of planetary management boundaries, an important place in which is taken by the planetary property and planetary rents as a form of income related to the use of planetary resources, including such a resource as land.

The institutionalization of planetary rent, unlike classic, is that it is a tool for solving global problems, can contribute to the formation and support of a unified order in resource usage - primarily environmental management, can be an incentive for technological and social development of economic entities, and focus on environmental conservation and social 
responsibility will become economically attractive and beneficial and, on a global scale, will act as the first and natural historical mechanism for worldwide integration into planetary humanity.

In the modern economic paradigm, such a type of natural space as forest acts as a significant system of value exchange and finds practical implementation in forest rents.

Modern development stage of national economic systems of Russia and Belarus and their agrarian and forest territories requires the solution of the institutionalization problem of planetary management boundaries in line with planetary scale rent relationship that can be of importance to the formation of the agro-industrial complex of the future.

\section{References}

1. O.E. Ryazanova, Transformation of the property institution in the context of globalization of the economy (Moscow Regional State University, Moscow, 2009)

2. Social rent as a phenomenon of the modern world. URL: http://www.gumer.info

3. E. Ostrom, Governing the commons. The Evolution of Institutions for Collective Action. (Moscow: Mysl, IRISEN, 2011)

4. T.V. Kashtelyan, Proceedings of BSTU, Series 5: Economics and Management, 2 (214), 46-51 (2018)

5. N.I. Bazylev, D.S. Krivulya, Planetary property, (M.: Misanta. 2012)

6. O.E. Ryazanova, V.P. Zolotareva, Digital Transformation of the Economy: Challenges, Trends, New Opportunities, 101-106 (2020)

7. A. Bezgodov, Planetary rent as a tool for solving global problems, (St. Petersburg: Piter, 2017)

8. T.V. Kashtelyan, Forest Journal, 1 (335), 40-50 (2017)

9. T.V. Kashtelyan, V.S. Berezovskaya, Statistical analysis of forest bioeconomics as an element of ensuring national ecological and economic stability, Statistical analysis of socio-economic development of subjects of the Russian Federation: Proceedings of the 7th International Scientific and Practical Conference, 189-192 (Bryansk State University of Engineering and Technology, Bryansk, 2020)

10. V. Gitz, A. Meybeck, Three perspectives for sustainable wood: global, landscape, value chainm URL: https://www.researchgate.net/profile/Alexandre_Meybeck

11. R. Makadok, Strategic Management Journal, 22 (5), 387-401 (2001)

12. J. Rockström, et al., Ecology and Society, 14 (2) (2009)

13. D. Schwab, E. Werker, World Development, 112, 33-45 (2018)

14. R. Torvik, Journal of Development Economics, 67 (2), 455-470 (2002)

15. L. Loft, C. Mann, B. Hansjürgens, Ecosystem Services, 16, 150-157 (2015)

16. C. Mann, L. Loft, B. Hansjürgens, Ecosystem Services, 16, 275-281 (2015) 